\title{
Culture of rabbit zygotes into blastocysts in protein-free medium with one to twenty per cent oxygen
}

\author{
Jianming Li and Robert H. Foote* \\ Department of Animal Science, Cornell University, Ithaca, NY 14853-4801, USA
}

\begin{abstract}
Embryos were collected from superovulated Dutch rabbits $19 \mathrm{~h}$ after injection of LH and insemination. The embryos were at the one-cell stage at that time and those judged to be normal by the absence of granular cytoplasm and regular shape were distributed randomly within donors into culture dishes containing $500 \mu \mathrm{l}$ of a macromolecule-free medium consisting of RPMI-1640 and low glucose Dulbecco's modified Eagle's medium, 1:1, without a cover of oil. In Expt 1, $\mathrm{O}_{2}$ concentrations of 5,10 and $15 \%$, with $5 \% \mathrm{CO}_{2}$ plus 90,85 and $80 \% \mathrm{~N}_{2}$, respectively, were tested. In Expt 2, $\mathrm{O}_{2}$ concentrations of 1,5 and $20 \%$ were combined with $5 \% \mathrm{CO}_{2}$ and the remaining gas was $\mathrm{N}_{2}$. After $84 \mathrm{~h}$ in culture at $39^{\circ} \mathrm{C}$, embryos were examined for stage of development and stained with Hoechst 33342 so that the number of cells could be counted. In Expt I, the proportion of embryos reaching the hatching blastocyst stage after $84 \mathrm{~h}$ in culture in 5,10 and $15 \% \mathrm{O}_{2}$ was 48,38 and $21 \%$, $(P<0.01)$ and the cell number per embryo averaged 258,226 and 188 , respectively $(P<0.01)$. In Expt 2, the proportion of hatching embryos after $84 \mathrm{~h}$ in culture in 1,5 and $20 \% \mathrm{O}_{2}$ was 67,72 and $29 \%(P<0.01)$, respectively. Cell numbers in the $\mathrm{I}$ and $5 \% \mathrm{O}_{2}$ concentrations were higher than in the $20 \% \mathrm{O}_{2}$ concentration $(P<0.01)$. These results indicate that reduction of $\mathrm{O}_{2}$ concentration to $5 \%$, well below the frequently used concentration of about $20 \% \mathrm{O}_{2}$ in $95 \%$ air, is beneficial to rabbit embryo development from the zygote to the blastocyst stage. The $\mathrm{O}_{2}$ concentration may be more critical with simple defined macromolecule-free media than in media containing serum.
\end{abstract}

\section{Introduction}

Good development of rabbit embryos in culture is possible with the use of a defined protein-free medium (Carney and Foote, 1991). However, development into blastocysts in vitro is inferior to preimplantation development in vivo, indicating that culture conditions are not optimal. This could be due to many factors, such as (I) deficiencies of some components in the medium, (2) toxic substances or toxic imbalances in the medium, (3) accumulation of toxic end products, (4) a suboptimal gaseous environment or (5) a combination of factors.

A common gaseous environment for embryo culture is $5 \% \mathrm{CO}_{2}$ and $95 \%$ humidified air (Wright and Bondioli, 1981; Biggers, 1987). Although $\mathrm{O}_{2}$ is important for energy producing metabolism, and $\mathrm{O}_{2}$ uptake increases as the embryo reaches the blastocyst stage in rabbits (Fridhandler, 1961) and mice (Mills and Brinster, 1967; Benos and Balaban, 1980), the $\mathrm{O}_{2}$ concentration in air exceeds the concentration of $5-8 \%$ in the rabbit oviduct (Bishop, 1956; Mastroianni and Jones, 1965; Bavister and Fischer, 1991). The rabbit embryo passes into the uterus before the blastocyst stage, so development during cleavage stages in vivo is in the presence of $5-8 \% \mathrm{O}_{2}$.

${ }^{*}$ Correspondence.

Received 12 June 1992.
The use of $5-10 \% \mathrm{O}_{2}$, or lower, with $5 \% \mathrm{CO}_{2}$ has been reported to be advantageous for preimplantation embryos of mice (Auerbach and Brinster, 1968; Whitten, 1971; Quinn and Harlow, 1978; Pabon et al., 1989; Umaoka et al., 1992), hamsters (McKiernan and Bavister, 1990), sheep (Tervit et al., 1972; Thompson et al., 1990), pigs (Wright, 1977) and cattle (Tervit $e t$ al., 1972; Wright et al., 1976a; Nakao and Nakatsuji, 1990; Voelkel and Hu, 1992). However, no advantage of the lower $\mathrm{O}_{2}$ concentration was reported for sheep by Wright et al. (1976b) and Betterbed and Wright (1985) or for cats (Johnston et al., 1991). When Voelkel and $\mathrm{Hu}$ (1992) cocultured bovine embryos with buffalo rat liver cells, $20 \% \mathrm{O}_{2}$ was superior to $5 \% \mathrm{O}_{2}$. Concentrations of $\mathrm{O}_{2}$ higher than $20 \%$ have been shown to be detrimental to mice (Quinn and Harlow, 1978) and rabbit embryos (Brackett, 1978).

The $\mathrm{O}_{2}$ concentration in the $95 \%$ air: $5 \% \mathrm{CO}_{2}$ system approaches $20 \%$ and this could result in various types of radical formation which might be toxic to the embryo under some in vitro conditions (Ellis, 1991). This factor could cause more detrimental effects in defined protein-free media where there is less chance for effects of free radicals to be ameliorated by high molecular weight proteins. Because of the lack of in vitro studies in the rabbits, the known low concentration of $\mathrm{O}_{2}$ in the rabbit oviduct and the recent ability to culture rabbit one-cell embryos to expanding blastocysts in macromolecule-free media, this study on various $\mathrm{O}_{2}$ concentrations was initiated. 
Table 1. Culture of rabbit zygotes for $84 \mathrm{~h}$ in RD medium (RPMI 1640:DMEM, 1:1) with various oxygen concentrations

\begin{tabular}{|c|c|c|c|c|c|}
\hline \multirow[b]{2}{*}{$\begin{array}{l}\mathrm{O}_{2} \text { concentration } \\
(\%)\end{array}$} & \multirow[b]{2}{*}{$\begin{array}{l}\text { No. of } \\
\text { embryos }\end{array}$} & \multicolumn{3}{|c|}{$\begin{array}{l}\text { Number of embryos at stage of } \\
\text { development in culture (\%) }\end{array}$} & \multirow[b]{2}{*}{$\begin{array}{c}\text { Total } \\
(\%)\end{array}$} \\
\hline & & $\begin{array}{l}\text { Early } \\
\text { blastocyst }\end{array}$ & $\begin{array}{l}\text { Expanding } \\
\text { blastocyst }\end{array}$ & $\begin{array}{l}\text { Hatching } \\
\text { blastocyst }\end{array}$ & \\
\hline 5 & 48 & $9(19)^{a}$ & $16(33)^{a}$ & $23(48)^{\mathrm{a}}$ & 100 \\
\hline 10 & 48 & $14(29)^{a}$ & $16(33)^{a}$ & $18(38)^{\mathrm{a}}$ & 100 \\
\hline \multirow[t]{3}{*}{15} & 48 & $26(54)^{b}$ & $12(25)^{\mathrm{a}}$ & $10(21)^{b}$ & 100 \\
\hline & & $P<0.01$ & $P>0.05$ & $P<0.01$ & \\
\hline & & \multicolumn{3}{|c|}{ Number of cells at $84 h^{*}$} & \\
\hline 5 & 30 & $258^{a}$ & & & \\
\hline 10 & 30 & $226^{\mathrm{b}}$ & & & \\
\hline 15 & 30 & $188^{\mathrm{c}}$ & $P<0.01$ & & \\
\hline
\end{tabular}

a,b, Numbers within columns with different superscripts are significantly different

*All embryos from a subset of four rabbits were examined.

\section{Materials and Methods}

\section{Medium}

Culture medium was similar to the RD medium of Carney and Foote (1991), but it contained the low glucose Dulbecco's modified Eagle's medium (DMEM, $1 \mathrm{~g} \mathrm{l}^{-1}$ ) mixed $1: 1$ with RPMI 1640, designated as RD medium. The final concentration of glucose was $1.5 \mathrm{~g} \mathrm{l}^{-1}$. This medium was stored at $5^{\circ} \mathrm{C}$ and before use, $2.85 \mu \mathrm{g}$ sodium bicarbonate was added per millilitre of RD medium. This medium was equilibrated at $39^{\circ} \mathrm{C}$ overnight in 4-well dishes (Nunc, Kastrup, Denmark) under the same gas conditions used for culturing embryos.

\section{Animals}

Dutch-belted rabbits were superovulated by a standard FSHLH schedule (Kennelly and Foote, 1965) and inseminated at the time of $\mathrm{LH}$ injection. This was timed so that $19 \mathrm{~h}$ later the oviducts were flushed with phosphate-buffered saline containing $1 \mathrm{mg}$ polyvinyl alcohol (PVA) $\mathrm{ml}^{-1}$ and one-cell zygotes were obtained in an air atmosphere. These zygotes were washed twice with RD medium. Normal zygotes from each donor rabbit, as judged by the absence of granular cytoplasm and presence of sharply defined perivitelline membrane, were randomly transferred as soon as possible into 4 -well dishes with each well containing $500 \mu \mathrm{l}$ of RD medium. Embryos were evaluated briefly after $24 \mathrm{~h}$ to determine whether any that were classified initially as zygotes were actually unfertilized oocytes. This occurred infrequently, but any such oocytes were removed.

\section{Culture}

The culture dishes were placed in tissue culture chambers with a water-filled dish to supply humidity; the chamber was regassed for $5 \mathrm{~min}$ with the appropriate gas, sealed and incubated at $39^{\circ} \mathrm{C}$, the approximate body temperature of rabbits.
The medium was replaced with fresh equilibrated medium after $48 \mathrm{~h}$.

\section{Evaluation}

After $84 \mathrm{~h}$, embryos were evaluated for stage of development and general appearance. A subset of all embryos from four of six donor rabbits in each experiment was stained with Hoechst 33342 and the number of cells was counted with the aid of an epifluorescent microscope.

\section{Experimental design}

In Expt 1 three gaseous environments of 5, 10 or $15 \% \mathrm{O}_{2}$ each with $5 \% \mathrm{CO}_{2}$ and 90,85 or $80 \% \mathrm{~N}_{2}$, respectively, were used. In Expt 2, 1 and $5 \% \mathrm{O}_{2}$, each with $5 \% \mathrm{CO}_{2}$ and the balance consisting of $\mathrm{N}_{2}$ were compared with the control environment of $5 \% \mathrm{CO}_{2}: 95 \%$ air. Each experiment was replicated across six zygote donors, with two donors used per day on three occasions. Zygotes from each donor were randomly distributed across all treatments. Cell number data were analysed by analysis of variance, in a mixed linear model with rabbits a random variable and treatments fixed. Differences among means were compared, using Tukey's HSD for pairwise comparisons. The proportions of embryos developing into blastocysts were analysed by chi-square.

\section{Results}

\section{Experiment 1}

Embryos developed into blastocysts in all treatments (Table 1). The high development rate occurred when males and females used were very fertile. A higher proportion of embryos cultured with 5 and $10 \% \mathrm{O}_{2}$ reached the hatching blasto- 
Table 2. Culture of rabbit zygotes for $84 \mathrm{~h}$ in RD medium (RPMI 1640:DMEM, 1:1) with various oxygen concentrations

\begin{tabular}{|c|c|c|c|c|c|}
\hline \multirow[b]{2}{*}{$\begin{array}{l}\mathrm{O}_{2} \text { concentration } \\
(\%)\end{array}$} & \multirow[b]{2}{*}{$\begin{array}{l}\text { No. of } \\
\text { embryos }\end{array}$} & \multicolumn{3}{|c|}{$\begin{array}{c}\text { Number of embryos at stage of } \\
\text { development in culture (\%) }\end{array}$} & \multirow[b]{2}{*}{$\begin{array}{c}\text { Total } \\
(\%)\end{array}$} \\
\hline & & $\begin{array}{c}\text { Early } \\
\text { blastocyst }\end{array}$ & $\begin{array}{l}\text { Expanding } \\
\text { blastocyst }\end{array}$ & $\begin{array}{l}\text { Hatching } \\
\text { blastocyst }\end{array}$ & \\
\hline 1 & 48 & $6(12)^{\mathrm{a}}$ & $10(21)^{a}$ & $32(67)^{\mathrm{a}}$ & 100 \\
\hline 5 & 50 & $5(10)^{\mathrm{a}}$ & $9(\mathbf{1 8})^{\mathrm{a}}$ & $36(72)^{a}$ & 100 \\
\hline \multirow[t]{3}{*}{20} & 49 & $10(20)^{b}$ & $25(51)^{\mathrm{b}}$ & $14(29)^{b}$ & 100 \\
\hline & & $P<0.05$ & $P<0.01$ & $P<0.01$ & \\
\hline & & \multicolumn{3}{|c|}{ Number of cells at $84 \mathrm{~h}^{*}$} & \\
\hline 1 & 35 & $252^{\mathrm{a}}$ & & & \\
\hline 5 & 30 & $262^{\mathrm{a}}$ & & & \\
\hline 20 & 32 & $204^{b}$ & $P<0.01$ & & \\
\hline
\end{tabular}

${ }^{a b} \mathrm{~N}$ Numbers within columns with different superscripts are significantly different.

${ }^{*}$ All embryos from a subset of four rabbits were examined.

cyst stage during the $84 \mathrm{~h}$ culture period, while more embryos cultured with $15 \% \mathrm{O}_{2}$ had developed only to the early blastocyst stage $(P<0.01)$. Thus, there was a difference in rate of development. Cell numbers also decreased as $\mathrm{O}_{2}$ increased $(P<0.01)$.

\section{Experiment 2}

There was no difference in embryo development between treatments containing 1 and $5 \% \mathrm{O}_{2}(P>0.05$, Table 2). Both treatments resulted in embryos with higher cell counts and more hatching embryos after $84 \mathrm{~h}$ of culture than embryos in $95 \%$ air:5\% $\mathrm{CO}_{2}(P<0.01)$. Thus, both experiments are in agreement indicating that embryonic growth in vitro is more rapid and probably superior in the presence of $5 \% \mathrm{O}_{2}$ than in $20 \% \mathrm{O}_{2}$.

\section{Discussion}

The majority of studies on $\mathrm{O}_{2}$ concentrations for culturing mammalian embryos favour the use of less than $10 \% \mathrm{O}_{2}$ for mice (Auerbach and Brinster, 1968; Whitten, 1971; Quinn and Harlow, 1978; Pabon et al., 1989; Umaoka et al., 1992), or 5 to $10 \% \mathrm{O}_{2}$ for sheep (Tervit et al., 1972; Thompson et al., 1990), pigs (Wright, 1977) and cattle (Tervit et al., 1972; Wright et al., 1976a; Nakao and Nakatsuji, 1990; Voelkel and Hu, 1992). Hamster oocytes were reported to have a distinct optimum at $5 \% \mathrm{O}_{2}$ for maturation (Gwatkin and Haidri, 1974). In a study with rabbits, Brackett (1978) reported no difference in fertilization of oocytes or early development of embryos in the presence of 20 versus $48 \% \mathrm{O}_{2}$. However culture was for $24 \mathrm{~h}$ only. Quinn and Harlow (1978) and Pabon et al. (1989) observed a delayed inhibitory effect of $20 \% \mathrm{O}_{2}$ on mouse embryos that occurred after culture for more than $24 \mathrm{~h}$. These latter workers found that exposure to $20 \% \mathrm{O}_{2}$ for as little as $1 \mathrm{~h}$ in medium devoid of macromolecules caused inhibition of development of mouse embryos after four to five divisions. In that regard it was similar to the RD medium used for rabbits in the present study.

In other studies no beneficial effect was found when $\mathrm{O}_{2}$ concentration was reduced (Wright et al, 1976a; Betterbed and Wright, 1985; Johnston et al, 1991). When bovine embryos were cocultured with buffalo rat liver cells, Voelkel and $\mathrm{Hu}$ (1992) found $20 \% \mathrm{O}_{2}$ to be superior to $5 \% \mathrm{O}_{2}$. Certain types of coculture system may require different $\mathrm{O}_{2}$ concentrations for optimal results. In addition, it is likely that the optimal concentrations of $\mathrm{O}_{2}$ differ according to culture media, species and stage of development. In the present studies the embryos were cultured without oil over the culture medium. However, it is likely that the results presented here apply to embryos cultured under oil, as Baltz and Biggers (1991) found that embryos cultured in microdroplets under silicone oil did not reduce oxygen tension significantly.

The improved development of rabbit embryos when cultured with $5 \% \mathrm{O}_{2}$ is consistent with $\mathrm{O}_{2}$ concentrations reported in the rabbit oviduct (Bishop, 1956; Mastroianni and Jones, 1965; Bavister and Fischer, 1991). It is also consistent with studies of other cell types (Ellis, 1991) where oxygen free radicals are more prevalent under higher oxygen tension. Umaoka et al. (1991, 1992) reported that reduction of $\mathrm{O}_{2}$ concentration from 20 to $5 \%$ and the addition of $500 \mu \mathrm{g}$ superoxide dismutase $\mathrm{ml}^{-1}$ increased the proportion of pronuclear mouse embryos developing into blastocysts during culture. Exposure of bovine embryos for as little as $1 \mathrm{~h}$ to $20 \%$ atmospheric oxygen, significantly decreased the rate of blastulation and addition of superoxide dismutase was beneficial (Noda et al., 1991). The handling of embryos in air after removal from the female reproductive system until culture may therefore be crucial.

Blastocyst-stage embryos consume considerable $\mathrm{O}_{2}$ and by 4 days produce $\mathrm{H}_{2} \mathrm{O}_{2}$ (Manes, 1992). It is not known whether this is toxic to the embryo, but this oxidizing agent appears to be toxic to totipotent cells in the inner cell mass of mice (Pierce et al., 1991). 
High $\mathrm{O}_{2}$ concentrations may interfere with anaerobic glycolysis. Substrate utilization can be affected by $\mathrm{O}_{2}$ concentration. Khurana and Wales (1989) reported that $1-5 \% \mathrm{O}_{2}$ in young mouse embryos is required to promote utilization of endogenous glycogen pools.

In the present studies we used a lower glucose concentration of $1.5 \mathrm{~g} \mathrm{l}^{-1}$ in the RD medium than previously (Carney and Foote, 1991). However, this is still higher than $0.2 \mathrm{~g} \mathrm{l}^{-1}$ found in oviductal fluid (Iritani et al., 1971). Glucose was inhibitory to development of hamster eight-cell embryos (Seshagiri and Bavister, 1989). Omission of glucose from the media during the period of maternal genomic control of development was beneficial for culturing mouse (Chatot et al., 1989) and cattle embryos (Ellington et al., 1990). The lower glucose concentration was helpful in culturing embryos of these species past the two-cell block. The rabbit embryo does not have this culture block, and appears to be more tolerant to glucose concentration. Glucose utilization by the rabbit embryo is low until embryos reach the blastocyst stage (Fridhandler, 1961), but obviously rabbit embryos develop in the presence of substantial glucose in the medium.

In conclusion, the optimal $\mathrm{O}_{2}$ concentration for culturing rabbit zygotes to hatching blastocysts in a macromolecule-free medium is about $5 \%$. This concentration is similar to the content in rabbit oviductal fluid. The gaseous environment is a relatively simple component of the culture system to control. Because of the positive results obtained here and in other studies, indicating deleterious latent effects of high $\mathrm{O}_{2}$ in other species following even relatively short exposure to air, it is suggested that minimal exposure to air during processing is desirable. The frequently used culture system of $5 \% \mathrm{CO}_{2}$ and $95 \%$ air should be discontinued for culture of rabbit embryos and should be critically tested in other embryo culture systems where currently used.

The authors acknowledge assistance of M. Simkin and L. Belanger and the NICHD National Cooperative Program on Non-human in Vitro Fertilization and Preimplantation Development, and was funded by the National Institute of Child Health and Human Development $\mathrm{NIH}$, through Cooperative Agreement HD 21939. Vetrepharm, Inc. (London, Ontario, Canada) kindly provided LH.

\section{References}

Auerbach S and Brinster RL (1968) Effect of oxygen concentration on the development of two-cell mouse embryos Nature 217 465-466

Baltz JM and Biggers JD (1991) Oxygen transport to embryos in microdrop cultures. Molecular Reproduction and Development 28 351-355.

Bavister BD and Fischer B (1991) What is the physiological oxygen tension for mammalian pre- and early postimplantation embryos? Journal of Reproduction and Fertility. Abstract Series 7 Abstract 4

Benos DJ and Balaban RS (1980) Energy requirements of the developing mammalian blastocyst for active ion transport Biology of Reproduction 23 941-947

Betterbed B and Wright RW, Jr (1985) Development of one-cell ovine embryos in two culture media under two gas atmospheres Theriogenology $\mathbf{2 3}$ $547-553$

Biggers JD (1987) Pioneering mammalian embryo culture. In The Mammalian Preimplantation Embryo, pp 1-22 Ed. BD Bavister. Plenum Press, NY.

Bishop DW (1956) Oxygen concentrations in the rabbit genital tract Proceedings of the Third International Congress of Animal Reproduction, Cambridge, pp 53-55 Brown, Knight and Truscott Ltd, London
Brackett BG (1978) In vitro fertilization: a potential means for toxicity testing Environmental Health Perspectives 24 65-71

Carney EW and Foote RH (1991) Improved development of rabbit one-cell embryos to the hatching blastocyst stage by culture in a defined protein-free culture medium Joumal of Reproduction and Fertility 91 113-123

Chatot CL, Ziomek CA, Bavister BD, Lewis GL and Torres I (1989) An improved culture medium supports development of random-bred 1-cell mouse embryos in vitro Joumal of Reproduction and Fertility $86679-688$

Ellington JE, Farrell PB, Simkin ME, Foote RH, Goldman EE and McGrath AB (1990) Development and survival after transfer of cow embryos cultured from 1-2-cells to morulae or blastocysts in rabbit oviducts or in a simple medium with bovine oviduct epithelial cells Joumal of Reproduction and Fertility 89 293-299

Ellis LC (1991) Free radicals in tissue culture. Part IV. Effects on cells in culture Art to Science 10(1) $1-2,4-5$

Fridhandler L (1961) Pathways of glucose metabolism in fertilized rabbit ova at various pre-implantation stages Experimental Cell Research 22 303-316

Fukui Y, McGowan LT, James RW, Pugh PA and Tervit HR (1991) Factors affecting the in-vitro development to blastocysts of bovine oocytes matured and fertilized in vitro Joumal of Reproduction and Fertility 92 125-131

Gwatkin RBL and Haidri AA (1974) Oxygen requirements for the maturation of hamster oocytes Journal of Reproduction and Fertility 37 127-129

Iritani A, Nishikawa Y, Gomes WR and VanDemark NL (1971) Secretion rates and chemical composition of oviduct and uterine fluids in rabbits Journal of Animal Science 33 829-835

Johnston LA, Donoghue AM, O'Brien SJ and Wildt DE (1991) Influence of temperature and gas atmosphere on in-vitro fertilization and embryo development in domestic cats Journal of Reproduction and Fertility 92 $377-382$

Kennelly JJ and Foote RH (1965) Superovulatory response of pre- and postpubertal rabbits to commercially available gonadotrophins Joumal of Reproduction and Fertility 9 177-188

Khurana NK and Wales RG (1989) Effects of oxygen concentration on the metabolism of $\left[\mathrm{U}^{14}-\mathrm{C}\right]$ glucose by mouse morulae and early blastocysts Reproduction, Fertility and Development 1 99-106

Manes C (1992) Cyamide-resistant reduction of nitroblue tetrazolium and hydrogen peroxide production by the rabbit blastocyst Molecular Reproduction and Development 31 114-121

Mastroianni L, Jr and Jones R (1965) Oxygen tension within the rabbit Fallopian tube Journal of Reproduction and Fertility 9 99-102

McKiernan SH and Bavister BD (1990) Environmental variables influencing in vitro development of hamster 2-cell embryos to the blastocyst stage Biology of Reproduction 43 404-413

Mills RM, Jr and Brinster RL (1967) Oxygen consumption of preimplanted mouse embryos Experimental Cell Research 47 337-342

Nakao H and Nakatsuji N (1990) Effects of co-culture, medium components and gas phase on in vitro culture of in vitro matured and in vitro fertilized bovine embryos Theriogenology 33 591-600

Noda Y, Matsumoto H, Umaoka Y, Tatsumi K, Kishi J and Mori T (1991) Involvement of superoxide radicals in mouse two-cell block phenomenon Molecular Reproduction and Development 28 356-360

Pabon WE, Findley WE and Gibbons WE (1989) The effect of short exposures to the atmospheric oxygen concentration on early mouse embryonic development Fertility and Sterility 51 896-900

Pierce GB, Lewellyn A and Parchment RE (1991) Polyamine-derived $\mathrm{H}_{2} \mathrm{O}_{2}$ regulates tissue mass during early murine embryogenesis In Vitro Cellular and Developmental Biology A 27 48A

Quinn P and Harlow GM (1978) The effect of oxygen on the development of preimplantation mouse embryos in vitro Joumal of Experimental Zoology 206 $73-80$

Seshagiri PB and Bavister BD (1989) Glucose inhibits development of hamster 8-cell embryos in vitro Biology of Reproduction 40 599-606

Tervit HR, Whittingham DG and Rowson LEA (1972) Successful culture in vitro of sheep and cattle ova Journal of Reproduction and Fertility 30 493-497

Thompson JGE, Simpson AC, Pugh PA, Donnelly PE and Tervit HR (1990) Effect of oxygen concentration on in-vitro development of preimplantation sheep and cattle embryos Journal of Reproduction and Fertility 89 573-578

Umaoka Y, Noda Y, Narimoto K and Mori T (1991) Developmental potentiality of embryos cultured under low oxygen tension with superoxide dismutase Journal of In Vitro Fertilization and Embryo Transfer 8 245-249

Umaoka Y, Noda Y, Narimoto K and Mori T (1992) Effects of oxygen toxicity on early development of mouse embryos Molecular Reproduction and Development $3128-33$ 
Voelkel SA and Hu YX (1992) Effect of gas atmosphere on the development of one-cell bovine embryos in two culture systems Theriogenology $\mathbf{3 7}$ $1117-1131$

Whitten WK (1971) Nutrient requirements for the culture of preimplantation embryos in vitro In Advances in the Biosciences, Vol. 6 pp 129-141 Ed. G. Raspe. Pergamon Press, Oxford

Wright RW, Jr (1977) Successful culture in vitro of swine embryos to the blastocyst stage Joumal of Animal Science 44 854-858
Wright RJ, Jr and Bondioli KB (1981) Aspects of in vitro fertilization and embryo culture in domestic animals Joumal of Animal Science 53 702-728

Wright RW, Jr, Anderson GB, Cupps PT and Drost M (1976a) Successful culture in vitro of bovine embryos to the blastocyst stage Biology of Reproduction 14 $157-162$

Wright RW, Jr, Anderson GB, Cupps PT, Drost M and Bradford GE (1976b) In vitro culture of embryos from adult and prepubertal ewes Journal of Animal Science 42 912-917 